\title{
Tax1-Binding Protein 1
}

National Cancer Institute

\section{Source}

National Cancer Institute. Tax1-Binding Protein 1. NCI Thesaurus. Code C137983.

Tax1-binding protein 1 (789 aa, $~ 91 \mathrm{kDa}$ ) is encoded by the human TAX1BP1 gene. This protein is involved in the inhibition of tumor necrosis factor-induced apoptosis. 